\title{
Mission and ethics in Galatians
}

\begin{abstract}
Author:
Jacobus Kok ${ }^{1}$

Affiliation:

${ }^{1}$ Department of New

Testament Studies,

University of Pretoria,

South Africa

Correspondence to:

Kobus Kok

email:

kobus.kok@up.ac.za

Postal address:

Faculty of Theology,

University of Pretoria,

Lynwood Road, Hatfield

0083, Pretoria, South Africa

Dates:

Received: 14 June 2010

Accepted: 30 Sept. 2010

Published: 07 June 2011

How to cite this article:

Kok, J., 2011, 'Mission

and ethics in Galatians',

HTS Teologiese Studies/

Theological Studies 67(1),

Art. \#896, 10 pages. DOI:

10.4102/hts.v67i1.896
\end{abstract}

(C) 2011. The Authors. Licensee: OpenJournals Publishing. This work is licensed under the Creative Commons Attribution License.
In this article, it is investigated how the concepts identity, ethics and ethos interrelate, and how the ethics of the Pauline communities in Galatians functioned against the background of the missionary context of the early church. The author argued that the missionary dimension originated in the context of the missio Dei, and that God called Paul as a missionary to be taken up in the latter. The missionary process did not end with Paul, but was designed to be carried further by believers who should be, by their very nature, missionary. In the process, the author investigated how the transformation of identity (the understanding of self, God and others) leads to the creation of ethical values and how it is particularised in different socioreligious and cultural contexts in the development of the early church. The author argued that there is an implicit missionary dimension in the ethics of Paul in Galatians. In the process, it is argued that those who want to speak of ethics should make something of mission, and those who speak of mission in Galatians, should speak about the role of identity, ethics and ethos in the letter.

\section{Introduction}

Recently, the Mo Ibrahim index revealed that South Africa, when one compares the amount of violent deaths and rape, that take place daily, statistically compares to countries that are in a state of war (see Van der Watt \& Kok 2010). In September 2009, the minister of police, Nathi Mthethwa, revealed the latest crime figures in parliament, in which no less than 2.1 million cases of crime have been reported in South Africa during the last year. ${ }^{1}$ Elsewhere, Kok (2010:1) has argued that South Africa is not only experiencing a moral crisis, but that after the transition into the New South Africa the mainline churches (and some members in that church) also experienced an identity crisis in the period. According to others, like the American scholar Campbell (2005:25), 'the global cultural shift and global phenomenon of postmodernity forced fundamental changes in the Western worldview', to the extent that 'the core beliefs, values and institutions of Western culture have been challenged' significantly in the last few decades. Campbell (2005:25) argues that 'we no longer have a cohesive system to explain reality' and that everything is becoming pluralistic and increasingly uncertain, 'accompanied by an increasing degree of social unrest'. In our zeitgeist questions like 'who am I' seems to be a fundamental question people ask, which is nothing less than a question about identity (Cambell 2005:25). Against this background of the growing context of crisis and disorientation concerning morality and ethics, a growing number of scholars are endeavouring research into ethics and/or morality and the way Christian ethics should be applied in a postmodern context (see Burridge 2007; Wolter 2009; Zimmermann \& Van der Watt 2010; Kok 2010; Du Plessis, Orsmond \& Van Deventer 2009). Burridge (2007:1) rightly argues that controversies about how to apply Biblical material to moral and ethical issues have always been a matter of debate within the history of the Christian church. Some of these issues relate to the prophetic role and self-understanding of the church in the pluralistic post-modern, post-Christian context of our multicultural world. As a Biblical scholar, I recognise the potential and need for deeper scientific reflection on ethics in the New Testament, with specific reference to the dynamics between ethics and mission and the resulting formation of moral agents and moral communities. It is not possible to suggest a constructive answer to the moral crisis in South Africa and the appropriate way to address the problem within the scope of this article. I would, however, like to argue that a scholarly and Biblical study of ethics in the New Testament is of utmost importance for contemporary society. Well known scholars in New Testament ethics like Burridge (2007:1-2), agree that the study of New Testament Ethics and the way we interpret scripture should be an ongoing process of academic reflection. Burridge (2007:1-2) rightly refers to an example within the context of the Dutch Reformed Church in South Africa, in which human relations were understood (within a scripturally based church) to support the doctrine of 'separate development', better known as apartheid. The General Synod of the Dutch Reformed Church accepted the doctrine of apartheid in 1976 and justified it ethically. A few decades later, after deep reflection and changes in the South African context, the same church confessed that the doctrine of apartheid was unethical and could no longer be justified on a scriptural basis. Burridge

1.See http://www.moibrahimfoundation.org/en/mifindex/ibrahimlndex?rnkitem=5 
(2007:3) is thus correct when he argues that it is necessary to keep on reflecting on the use of the Bible in ethics (cf. also Du Plessis, Orsmond \& Van Deventer 2009) and the way that Christian ethics is to be lived out in a concrete ethos (lifestyle). It is against this background that I investigate the dynamic relationship between mission and ethics in the early church, with specific reference to Paul.

In this article, it will be investigated how the concepts identity, ethics and ethos interrelate and how the ethics of the Pauline communities in Galatians functioned within the background of the missionary context of the early church. It will thus be investigated how the transformation of identity (the understanding of self, God and others) leads to the creation of ethical values and how it is particularised in different socio-religious and cultural contexts in the development of the early church.

In this article, the dynamic relationship between mission and ethics in the New Testament, focusing on Paul's letter to the Galatians, will be investigated. Much has been written on Ethics and Morality ${ }^{2}$ in Paul on the one hand ${ }^{3}$ and on Paul as missionary on the other, ${ }^{4}$ but little on the dynamics between Ethics and Mission in Paul. ${ }^{5}$ The need for this article is positioned against the background of the growing interest in the missiological dimension of the church, as seen in the worldwide flux of recent publications on the subject ${ }^{6}$ and the rapid growth of Christianity in Africa (especially amongst the indigenous peoples) over the last few decades (Jenkins 2002:1-15, 79).

With regard to missional theology and the practice of mission, missiologists have in recent years become ever more

2.When using the term 'morality' in combination with mission, I mean thereby that it relates to principles of right and wrong in behaviour: Ethical moral judgments; expressing or teaching a conception of right behaviour; conforming to a standard of right behaviour; sanctioned by or operative on one's conscience or ethical judgment right behaviour; sanctioned by or operative on one's conscience or ethical judgment (a moral obligation; capable of right and wrong action (a moral agent) (MerriamWebster 2003:341). Morality could thus be seen as a 'system of moral conduct' which presupposes not only rules and regulations of what is right and wrong, but also the underlining and implicit change of identity that occur in the process of mission and the ethos or lifestyle that flows from that. Meeks (1993:3) is of the opinion that it is not possible to speak of the term 'New Testament ethics' when historical study of the New Testament letters is conducted due to the fact that 'the New Testament as we know it had not yet fully taken shape'. According to Meeks (1993:3) we should rather speak of early Christian morality than of New Testament Ethics. In this article, however, the term 'moral' is used in an inclusive way to refe to identity, ethics and ethos in the particular New Testament document unde investigation. Moralis denotes principles of right and wrong, or the expression or teaching of what is morally right or wrong behaviour, ways of thinking or being, etcetera. Morality do not only give indication of what is right or wrong behaviou within a particular society, but also directs behaviour towards that which is seen as within a particular society, but also directs behaviour towards that which is seen as being the standard of right behaviour. In this way, I follow Zimmermann (2009:399), that the New Testament does in fact contain implicit ethics and that it is possible to speak of New Testament ethics, unlike Meeks. I do however agree with Meeks (1993:4) that ethics is to be understood as 'morality rendered self-consciously', it has to do with the logic of moral discourse and action, or the roots and structure of Christian virtue.

3.Cf. Wolter (2009:121-167) and especially the chapter titled 'Identität und Ethos bei Paulus' [Identity and Ethos in Paul]. See also Zimmermann $(2007: 259,284)$ and Schnelle (2003:109-131)

4.Lietaert Peerbolte (2003); Reinbold (2000); Le Grys (1998); Gager (2000); EngbergPederson (2000); Dunn (1998); Sanders (1983:171-206).

5.Recently a study appeared in which Du Plessis, Orsmond \& Van Deventer (2009) discussed the challenges of mission and the way the New Testament presents perspectives on these challenges. They also discussed the emergence of the missional church in the Dutch Reformed church in South Africa.

6.Cf. Hirsch (2006); Niemandt (2007); Keifert (2006); Roxburgh (2005); Lietaert Peerbolte (2003); Bosch (1999: 226-230 and 302-311); Newbigin (1995:6); Robert (2005:412); Nissen (2007). sensitive to the errors that have been made in the past with reference to mission to indigenous cultures: in the process of missional endeavours from the developed world, it more than often happened that the ethical values of the developed world have been imposed on indigenous cultures. ${ }^{7}$ The social values of the developed world were seen as 'gospel', and in the process, missionaries have not always been sensitive to the social ethics of indigenous cultures as Dana L. Robert ${ }^{8}$ expresses it well:

Mission at its worst ran the danger of cultural imperialism, of imposing western lifestyles and values to the destruction of indigenous ones. Critics have charged that the modern missional movement was little more than a sustained attempt to impose Euro-American culture on the peoples who came under its sway. To be sure, the missionary drama was played out on the same stage as the powerful political and economic developments of the period; missions were stained by its association Western imperialism. By virtue of its global reach the movement became a primary carrier of modernity and the artifacts and institutions associated with modernity early became hallmarks of missions.

(Robert 2005:412)

We have indeed learned from mistakes made in the past, but also need to keep on learning and exploring new horizons on an ongoing basis. In this article, the dynamics between mission and ethics and ultimately what we could learn from Paul's missionary approach, will be investigated. How, in other words, is the dynamics between mission and morality in Paul, in the course of the missionary process, to be understood in a post Christian, post modernistic and cultural pluralistic context against the background of mission?

\section{Mapping the field: Clarification of important concepts identity, ethics, ethos and mission}

Firstly, it is necessary to define the terms 'Identity', 'Ethics' and 'Ethos' (Van der Watt 2006:v-ix). The term 'Ethics' is to be understood as a generic term referring to the moral codes, values, principles and norms in a particular society based on the systematic reflection upon the latter (Van der Watt (2006:vviii). I agree with Zimmermann (2009:399-400) that the term 'ethics' could thus be defined as the 'systematic-theoretical examination' of a lived ethos, in which he follows Aristotle (An. Post. 1.33-89b 9). Ethics is thus concerned with the 'rational analysis of morals, the critical examination of ethos and the subsequent questioning of the motives of morality' (Zimmermann 2009:400).

'Identity' relates to the question of who we are, the values we live by on the basis (motivation) of how we understand ourselves, our relationship to God and the world and the values, rules and principles we defer from that.

'Ethos', on the other hand, is to be understood as the practical

7.Cf. Bosch (1999:15) speaks of 'mission as the mother of theology'.

8.See also Bosch (1999:226-230 and 302-311) for a discussion on colonialism and mission, as well as Newbigin (1995:6) for a discussion on the domination of the developed world in missionary contexts. 
way we live out our ethics (Lebensstil, ${ }^{9}$ practical life style) in a given socio-historical and cultural context (Van der Watt 2004:2-3), the way we do things in our society or group, the institutionalised practices.

As Christians, the basis or motivation of our being should be built on the basis of a particular understanding of God, the world and God's story ${ }^{10}$ for and/or with the world, ${ }^{11}$ which by implication includes the missionary dimension and Universal Godly Narrative (UGN). ${ }^{12}$ Accordingly, it could be argued that there exists a dynamic inter-relational correspondence between identity, ethics and ethos on the one hand. On the other hand, that the inter-relational dynamics thereof are always implicitly imbedded and particularised within a specific socio-historical context has to be taken into consideration. This was the case in Paul's missionary endeavours, and will also be the case today, when we do mission.

This brings us to the question as to what we understand under the term 'mission'. In most cases one will find that the denotative, associative and connotative meanings of 'mission' are understood in a centrifugal way. That is at least the case in my native language, Afrikaans. The Standard Afrikaans Dictionary defines 'Sending' (mission) as follows (Odendal 1994: ad loc):

- handeling van te send, te stuur [Action of sending someone]

- opdrag, taak wat elders verrig moet word: op 'n diplomatieke sending in Moskou wees. Vredesending [A task that has to be done somewhere else: To be on a diplomatic mission in Moscow]

- al die werksaamhede van Christen-sendelinge en die administrasie daarvan: Die binne- en buitelandse

9.Leander E. Keck (1979:13-36, 13-26) understands ethos as: 'Lebensstil einer Gruppe oder Gesellschaft' [The life style of a group or community].

10.When referring to the plan of God or God's story of the world, my presupposition is that there exists a strong relationship between the Old and New Testament, with is that there exists a strong relationship between the Old and New Testament, with fulfilment of, not only OT scripture, but also of the Jewish Messianic expectations. I therefore do not agree with some scholars like Schnelle (2009), who stand upon I therefore do not agree with some scholars like Schnelle (2009), who stand upon a
stronger discontinuity between the Old and New Testament. According to me, Paul stronger discontinuity between the Old and New Testament. According to me, Paul
at least, interprets the Christ event as fulfilment of the Old Testament expectations and within the framework of the OT covenant (For a similar approach, see Wrigh (2003).

11.In John's gospel for example, God loved the world (3:16), which is caught up in darkness, sin and blindness $(5: 24 ; 9: 41 ; 12: 40)$, and in essence became evil children of the devil (8:44). For this reason, God sent his only Son so that those who believe in him could have eternal life $(3: 16 ; 20: 30-31)$, become part of a new family, and in him could have eternal life (3:16,20:30-31), become part of a new family, and be the children of God (1:12). It could thus be argued that in John for instance, soteriology implies re-socialisation and entrance into a new social reality, which for perves as the basis for the formulation of the believer's sochics. Th for Paul in Galatians, the believer becomes part of a new family (cf. Gl 3.21-4:7, 4:28; $\tau \varepsilon \kappa v \alpha[$ [children]). Therefore, a fundamental interrelational correspondence exists between ethics and ethos. Conduct is a result of identity and therefore ethos is always a result of, and related to ethics, rooted in a particular understanding of the Universal Godly Narrative. Ethos is, in other words, the Lebensstil or conduct of those who share a common identity. The understanding of Ethics and Ethos is a dynamic social process as a result of its realisation within a specific socio-historical context. Van Rensburg (2004:3) explains it as follows: 'The basis motivates the ethics, which in turn is practiced as ethos, which receives approval and/or disapproval from society. This may result in the ethos being reconsidered in the light of the basis, and this either reinforces or reconstitutes specific behavio (ethos), etc'. The term ethos also has a heuristic function, in the sense that it refers to the ethics. In other words, to develop a missional-incarnational ethos, we have to the ethics. In other wo have to have a particular view of ethics, which is based on a particular understanding of

2.With the term Universal Godly Narrative (from now on UGN) the Story of God and his plan for the world, as articulated in the New Testament Literature is referred to (cf. Jn 3:16, etc). sending. Die sending onder die Jode, Islam. [All the duties of Christian missionaries and the administration thereof].

These kind of centrifugal definitions are enormously problematic, in the sense that they tend not only to pacify congregations and believers as such, but also that 'mission' becomes something that someone else does, somewhere far away. I concur with scholars like Keifert (2006:167-168), that the Pauline understanding of mission is far removed for the latter definition and understanding that prevail in some churches today. Mission, rather, is something far greater than the church, a dimension in which the missional church is to be taken up into, and carry out God's mission (cf. also Bosch 1999). A missional church is rather a church that does not simply do mission, but that focuses on being missional (Keifert 2006:168).

\section{The dynamics of mission in Paul The origin of the missionary dimension: God's plan in action}

In Paul and in the New Testament per se, it is clear that the totality of the missionary dimension originates from God (cf. Gl 1:4). It is, in other words, not the story of people doing missionary work, but of people being taken up in the missionary dimension or story ${ }^{13}$ of God and his Son (missio $\left.D e i^{14}\right)$, with the implication that the definition of mission should, in the first instance, reflect the missio Dei. This becomes clear in the opening verses of Galatians, where Paul clearly states that the fact that he is an apostle (missionary)

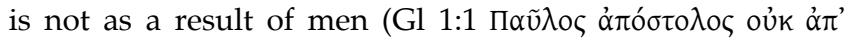

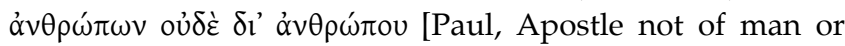
through man]), but because of God (cf. also Gl 2:8), who

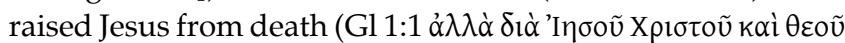

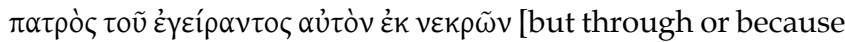
of Christ and God the father who raised him from death]). The life-transforming message that Paul preaches thus has as its origin the revelation of God, Paul argues, and not merely that of men (Gl 1:11-12).

Furthermore, Paul's sending as an apostle is not seen as something that takes place in isolation, but realises against the background of the UGN, according to which God has

13.In recent debates in political theory and also in contemporary discussions in Christian Ethics, there is a difference between the view of the so-called liberals and Christian Ethics, there is a difference between the view of the so-called liberals and checratic public morality in which every person chooses their own way of life and view of that which is good. Communitarians, on the other hand, argue that people's identity and ethical values are formed in the context of communities. I agree with Hauwerwas (1983:99-100), who argues from a Christian communitarian point of view, that the community of faith is called to be a particular kind of people, based on a particular story (that has God as the main character), a story which not only shapes their identity as children of God, but also sustains it (See also The Significance of Paul's story (Longenecker \& Horrel 2002:210-211). This however, does not mean that the ethical norms and ethical action of the church is necessarily different to that of the world. In many cases it would correspond to the ethical norms of other traditions. The difference would be the motivation thereof.

14.See Bosch (1999:389-392) for a discussion on Mission as missio Dei. The latter could be described in the following way: 'Mission is understood as being derived from the described in the following way. "Mission is understood as being derived from the very not of Father sending Father sending the Son, and God the Father sending the Spirit is expanded to include yet another "movement": Father, Son, and Holy Spirit sending the church into the world' (Bosch 1990:390). 
sent his Son to deliver or save ( $\dot{\xi} \xi \hat{\varepsilon} \lambda \eta \tau \alpha$ [rescue]) the world (Gl 1:4). In Galatians, Paul states that the whole world is caught up in the grip of $\sin \left(\mathrm{Gl} 3: 22 \dot{\alpha} \lambda \lambda \dot{\alpha} \sigma u v \varepsilon \varepsilon^{\prime} \lambda \varepsilon l \sigma \varepsilon v \dot{\eta} \gamma \rho \alpha \varphi \grave{\eta}\right.$

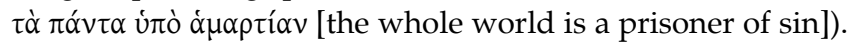

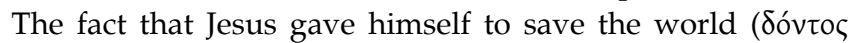

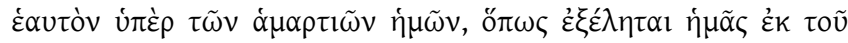

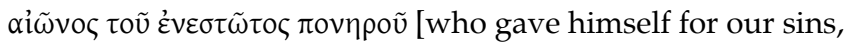
to rescue us from this evil age]) is, according to Paul, based on

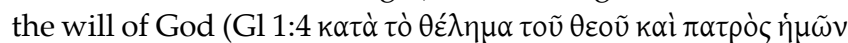
[according to the will of God our father]). There where people are subsequently saved from this evil age (Gl 1:4) or where the transforming message is preached or lived, there a very important part of the missionary process, of God's mission, is already taking place. When the missionary dimension in Paul is discussed, in other words, one should not make the mistake to limit the scope thereof to a mere focus on the end result of the missionary process, but rather start with its origin. In most books and articles on the subject, one will find that the authors focus more on the result of the missionary process than on the origin and motivation thereof. ${ }^{15}$ The implication of the former approach is that the focus of the missionary dimension falls more towards the result of the missionary process, where conversion has taken place, or where a missionary takes the action to go out and convert. The pendulum moves more towards the result of the missionary process than towards the origin thereof, with the result that not much is made of the theological (and ethical) dimension that serves as the motivation for the mission. The further implication is that only that which refers to the end result of mission is regarded as mission. In the process an important dimension of the missionary process is not discussed or recognised as part of the missionary dimension, with the result that much of the implicit missionary dimensions in the New Testament are not taken into consideration. ${ }^{16}$

\section{God the sender sends Paul the missionary}

Paul is well-known as the planter and founder of communities

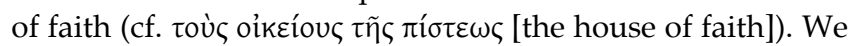
know the 'dass' of the fact that he found new communities of faith but have little historical evidence of the 'wie' or how he

15.See for instance Lietaert Peerbolte (2003) who tends to see mission as the conversion of people towards Jesus or God and the sociological group formation that follows from that.

16.This brings us to the important thesis that will be investigated in this article. In my opinion, there does not only exist a dynamic inter-relational correspondence between identity, ethics and ethos, but also between the latter and the missionary movement of the early church. This becomes clear when the missionary process is viewed from the perspective of its origin (God and his mission) and also from the perspective of the message being incarnated in the messenger or in the context of the community of faith. Said differently, as the Gospel was preached to unbelievers in the missionary process, the gospel inevitably transformed many with regards to not only their identity, but also their ethos and ethics. As the new born believer experienced conversion (cf. Rm 12:2), they received a new identity and belonged to a new group or family (See Van der Watt 2000:211), in which a new set of rules (ethics) had to be excepted and functionally displayed and concretised in a new way of life (ethos) which was taken up within the missionary dimension and will of God (Van der Watt 2006:vii). It could thus be argued that mission inevitably stands in an inter-relational relationship (inter-relationalen Beziehung) to identity, ethics and ethos. The implication thereof is that the missionary dimension entails much more than the mere sending out of someone, but also the embodiment of the missionary message per se. Therefore, in this article, I will investigate Paul's letter to the Galatians within the analytical framework and inter-related categories of identity, ethics, ethos and mission and the inter-relatedness thereof went about in forming these communities. Paul's missionary endeavours obviously entailed a particular sociological process that could be divided in different stages. The first stage would be his contact with a particular community or a group of individuals, to which he preached the Gospel, and the second entail the process of forming a community that naturally followed. Lietaert Peerbolte (2003:204) rightly asks whether Paul purposefully went out to create a new community when he visited a town or city, or whether the reality of group formation was an unforeseen result of the process of Paul's preaching. Here it is best to investigate, as far as possible, Paul's own way of describing his missional activities. Pesce (1994:12) argues that we do not have available historical evidence, or literary sources for that matter, that explicitly refer to the so-called first stage of group formation, where Paul met individuals or a group of individuals and the way he went about the missionary process. We have only the second stage of evidence, in which the community has already been formed, and in which Paul writes to an existing faith community. Therefore, Paul's letters 'do not offer direct access to Paul's preaching of the gospel and the subsequent formation of the communities that resulted from this activity' (Lietaert Peerbolte 2003:205).

Nevertheless, we do have textual witnesses of how Paul described his own work in retrospect, for instance in Galatians

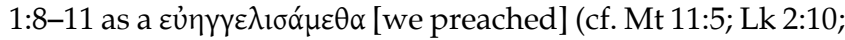
3:18; Ac 5:42; 10:36; Rm 1:15; 10:15; Gl 1:8; Eph 2:17; 1Th 3:6; Heb 4:6; $1 \mathrm{Pt} 4: 6 ; \operatorname{Rv} 10: 7 ; 14: 6)$, or the telling of the good news.

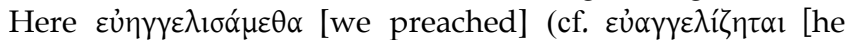

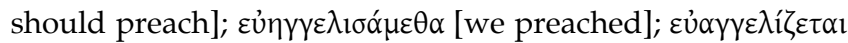
[he is preaching] in Gl 1:8-11) is written in the aorist medium voice, indicating that the faith community in Galatia received the gospel as it was preached unto them by Paul when he made the Gospel known (cf. Gl 1:7) to them. Paul is thus the instrument that told them about the good news that God

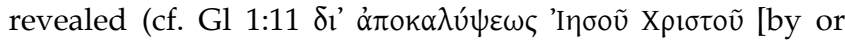
through a revelation of Jesus Christ]) to him. In Galatians

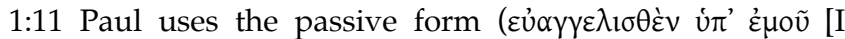
preached]) to emphasise the fact that this good message

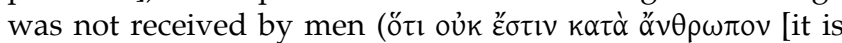

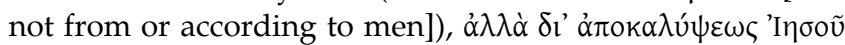

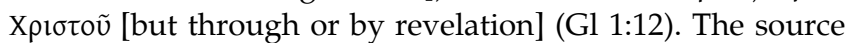
of this gospel, or good news is the same God who, within his original plan, sent not only his Son, but also the apostle Paul. The message Paul preaches and embodies thus comes

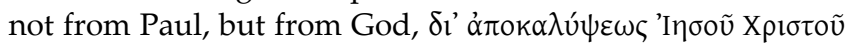
[revelation]. This undoubtedly presupposes the fact that as Paul 'passively' received the gospel through revelation from Jesus Christ, it nevertheless derives from God and from his will, and is therefore part of his plan and ultimately originates (in the language of mission) from the missio Dei. Every element of the missionary dimension thus has as its origin the original plan of God. For this reason, Paul can also argue that he was not appointed by any man, but by Jesus Christ and by God the Father who raised Jesus from death (Gl 1:1

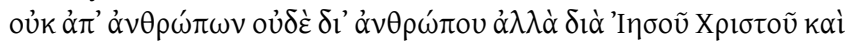

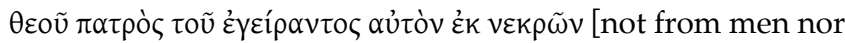
by man, but by Jesus Christ and God the Father who raised

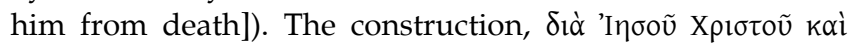




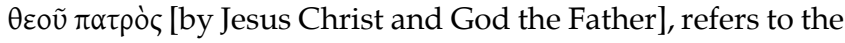
close connection and inter-relatedness between the Father and the Son in the context of the missional dimension. Paul is thus taken up in the missio Dei, into the greater story of Jesus Christ and God's purposes with the world. The sending of Paul is thus fundamentally inter-related to the plan of God, the sending of the Son and the UGN. Therefore, Paul would often refer to the (spiritual) work being done in the the lives

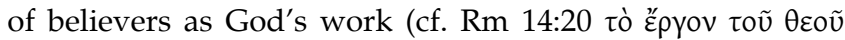
[the work of God]) and as such, something that God will

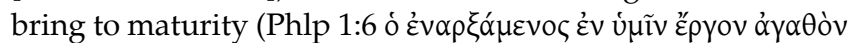
$\dot{\varepsilon} \pi \iota \tau \varepsilon \lambda \varepsilon \dot{\sigma \varepsilon l}$ [he who began a good work in you will perfect or complete it]).

In the introductory part of the letter (Gl 1:4), Paul gives

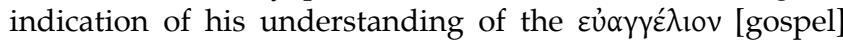

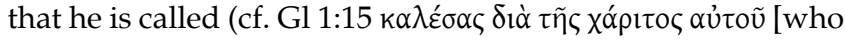
called me through or by his grace]) to preach:

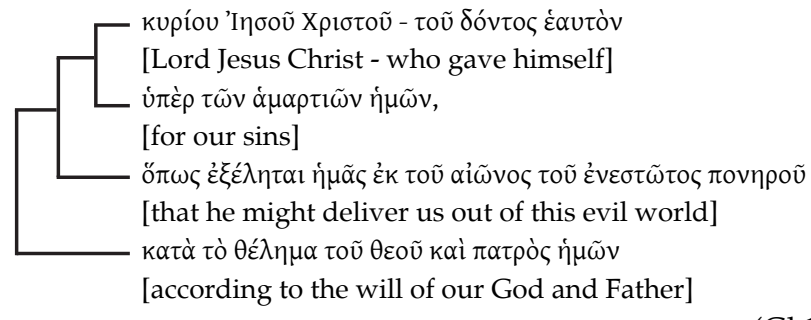

From the aforementioned text we could infer that in Paul's mind and theological understanding, his mission is be interpreted as part of something God is doing, or which God is up to in the world, namely that it is the will of God (cf. katà tò

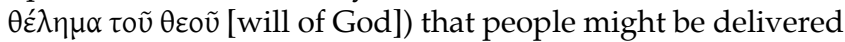
(cf. $\dot{\xi} \xi \dot{\xi} \lambda \eta \tau \alpha_{1}$ [delivered]) out of or from this present evil age

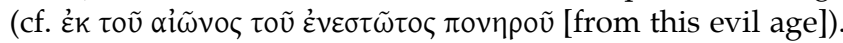
In reality, the whole world, Jews and Gentiles alike, are

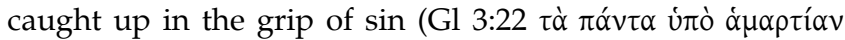

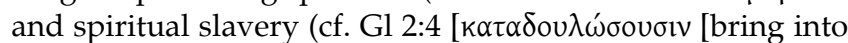

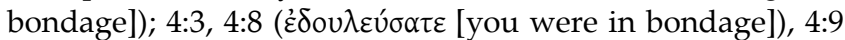

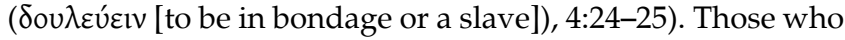
do not believe are in other words not free, they are caught

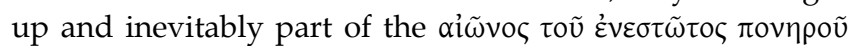
[this eveil age], and although they might not realise it, they are desperately in need of deliverance from this bondage to sin (see Gl 3:22). God not only called Paul by grace (Gl 1:15), he also called him with a very definite purpose, namely to

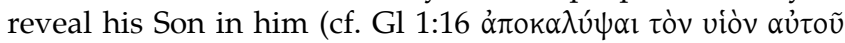

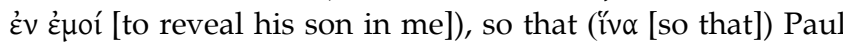
would proclaim and preach him amongst the nations (iv $\alpha$

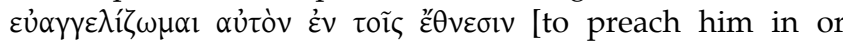
amongst the nations]). Paul, in other words, understood his calling as mission and his missional preaching as a calling with universalistic ${ }^{17}$ implications (Nissen 2007:60).

17.According to Wright (2003), the term 'justification' in Paul is the original ecumenical doctrine. He refers to Galatians 2 and argues that it is in Galalatians 2 where it is about people from different cultures and traditions sharing tablefellowship on the basis of nothing other than their shared faith in Jesus as Messiah and Lord. Those who share faith in Jesus are those who have been declared as being justified and who should in obedience continue to live in Christ. Accordin being justified and who should in obedience continue to live in Christ. According to Wright, the doctrine of justification itself urges and compels us to unite across our cultural divides, due to the unity that exists in Christ. For Wright (2003) then, the polemic against the Torah in Galatians is not to be seen as a polemic against some form of self-help moralism or against the more subtle snare of 'legalism', but against references to the Jewish law, seen as the national charter of the Jewish race (identity markers if you wish), which separates those who are in and those who are out. In other words, the whole debate about justification in Galatians, 'wasn't

\section{An ontological transformation with universalistic implications}

Before his conversion to Christ, Paul was a zealous Pharisee following the law, ${ }^{18}$ living a life characterised by an extremely high Jewish morality (cf. Phlp 3:4-5), but nevertheless a slave to the law. Accordingly, there existed for him a compelling irreconcilable difference between Jew and Gentile (and Christian) and he zealously persecuted the followers of Christ (Gl 1:13). After his conversion, ${ }^{19}$ Paul's identity was radically redefined (Cromhout 2009:135). Although he retained much of his Jewish faith elements (Cromhout ${ }^{20}$ 2009:126; Burridge 2007:107; Kok 2010b:1; Gager 2000; Sanders 1977, 1983; Wright 2003:1-2; Dunn 2008:5-9; Hawthorne, Martin \& Reid 1993:306), and was still on an ethical level aligned with some of the elements that are to be interpreted as typically Jewish and Pharisaic (cf. his sexual ethics [1 Cor 5], his use of Old Testament (OT) Scripture, covenant, etcetera [Wright 2003:6]), it was nevertheless reinterpreted through his experience of the Christ event (cf. Phlp 3:7). Paul realised his identity by making the Christ-event metaphorically part of his self understanding. He soon understood, however, that Christ was sent (Gl 4:4) to redeem us all from the curse of the $\operatorname{law}^{21}$ (Gl 3:10), that had become a curse for us (Gl 3:13). ${ }^{22}$ This newly found freedom changed Paul's identity, ethics and ethos and his paradigm of God, people and life. This new paradigm called forth a reevaluation of his whole outlook on life. In Galatians 2:19-20, Paul states that he has been

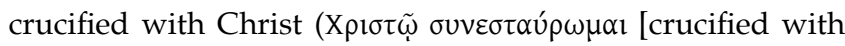
Christ]), and it is no longer he that lives, but Christ living in

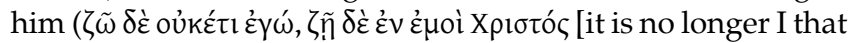
live, but Christ living in me]). He now lives a life of faith and

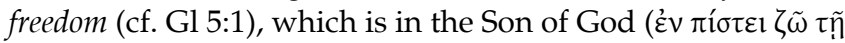

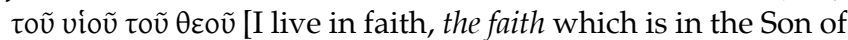
God - Gl 2:20]), who loved him and gave himself up for him. In Paul's conversion or calling, he was radically transformed from the inside out. Paul himself was delivered from this evil age and from bondage and experienced the freedom (and xópıs [grace], cf. Gl 1:6, 15; 2:9; 21; 5:4; 6:18) in Christ that he later would wholeheartedly proclaim. ${ }^{23}$ The message of

(Footnote 17 cont...)

so much about soteriology as about ecclesiology; not so much about salvation as about the church'.

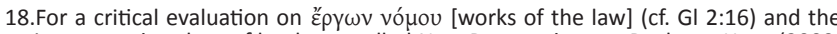
interpretation thereof by the so called New Perspectives on Paul, see Horn (2009: 213-234)

19.See Du Toit (2007:57-76). See also Dunn (2008:20-39) who makes the Damascus experience of Paul a very important element in the transformation of Paul's life and subsequently his view on grace, works of the law, etc.

20.See Cromhout (2009) who discusses the various arguments about Paul's 'Jewishness or Judeanness' as a follower of Jesus Messiah, for instance that Paul essentially remained to be 'Jewish or Judean' and after his conversion fully operated within the world of 'Judaism'. Cromhout investigates these claims by answering three the world of 'Judaism'. Cromhout investigates these claims by answering three
sets of questions derived from a proposed general model of ethnicity theory. He comes to the conclusion that Paul 'continued to see himself as an Israelite, but who belonged to his 'Israel', which, at least for the moment, was radically transformed, with (mostly) Gentiles being grafted in and (mostly) traditional Israelites placed without' (Cromhout 2009:135).

21.For a positive view of the law and Paul's view that the will of God is also to be found in the law, see Rm 2:14. According to Wright (2003), Paul was not against the law, just the wrong understanding of the law.

22.See Breytenbach (2005:163-185) who argues that Paul took over the tradition that Christ 'died for our sins' and consequently developed his interpretation of Christ's death in four ways, namely by personalising it (making it part of his identity); universalising it; and by making it an expression of God's love and by highlighting that this death resulted in salvation.

23.Breytenbach (2005:183) is correct in arguing that 'Paul understands Christ's 
deliverance and freedom from bondage and spiritual slavery became intrinsically part of his missionary message, the good news that had the potential to radically transform the world and bring vertical (God-humans) ${ }^{24}$ and horizontal (humanshumans) reconciliation.

For Paul, his missionary calling and the preaching of the gospel is to be seen as in direct opposition to the powers of this world. Hahn (1965:99) goes so far as to say that the powers

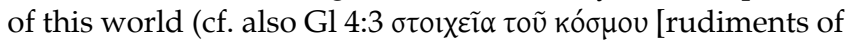

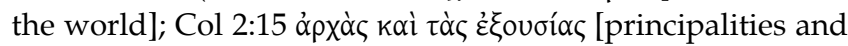
powers]) are overcome by the preaching and spreading of the gospel, and Paul is led in a triumphal march through the countries whilst propagating the savour of Christ (cf. 2 Cor 2:14ff; see Col 2:15). This is true when the high Christology of Paul (cf. Phlp 2:5-10; Rm 10: 9-13; 14-18; 15:7-13) is taken into account. Hahn (1965) argues that:

On these presuppositions (of the high Christology) the mission to the gentiles can no longer be for Paul an exceptional phenomenon. From the concept of the exaltation he realised, as no one before him, the all-embracing reality of the Christian message, and he understood that the gospel itself, with its universal claim, demands that the mission should be to all human beings, including the 'Greeks and barbarians'.

(Hahn 1965:99)

From this high Christology as the point of departure, Paul could thus proclaim boldly that, through faith, all who believe

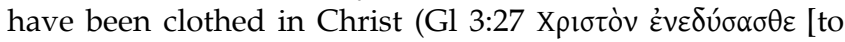
put on Christ]) and receives a new identity (cf. Gl 6:15-16). This new identity is also expressed in kinship language. Paul uses the metaphor of a family and argues that believers are no longer slaves but have become (freed) children of God (Gl

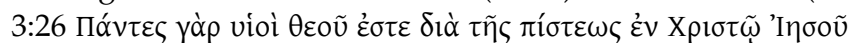
[For you are all sons of God, through faith, in Christ Jesus]), spiritual heirs of God's testament of inheritance (cf. Gl 3:21-4:7). ${ }^{25}$ They have been changed from one state of being (bounded slaves) into a new one (freed children of God), which comes down to nothing less than being new creatures

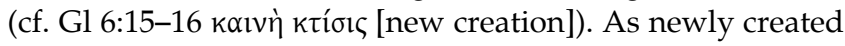
children of God, they are thus taken up in the family of God and have received a new identity. Soteriology, in other words, implies a particular re-socialisation and entrance into a new social reality, which also serves as the basis for the formulation of the believer's ethics (Van der Watt 2005:124). The fact that believers have all become children of God, naturally implies that there is no difference between Jew or Greek, slave or free person, or even men and woman: In

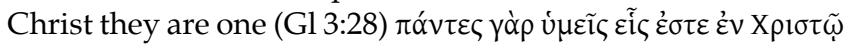

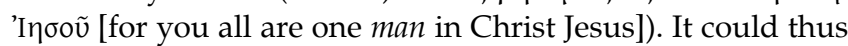
be argued ${ }^{26}$ that the concept of freedom in Christ belongs just

(Footnote 23 cont...)

beneficiary death 'for' us as a prolepsis of the eschatological judgment in which the old existence was terminated. This opens the possibility for a newly created humanity in Christ'.

24.Clearly in 2 Corinthians 5:17 and onwards, we see that God claims the world as his creation by reconciling the world to himself, creating a new creation (cf. 2 Cor $5: 19,21)$.

25.In the act of proclaiming this message of freedom and reconciliation, Paul deconstructed and challenged the prevailing world view and paradigm of both Jews and Gentiles. Some opposed him, whilst others were taken up by the radicality of this new paradigm of faith. For them the message of good news changed their paradigms, their identity, their ethics and their ethos.

26. Hahn (1965:101) follows this train of thought. as much as universality to the Gospel. In other words, from the high Christology as point of departure all socio-cultural and religious barriers between people dissolve, ${ }^{27}$ which inevitable opens up the missionary (universal) dimension. ${ }^{28}$

According to Galatians 4:8, at least some members of the faith community Paul is writing to were people who previously did not know God, and who worshipped pagan idols. In due time (within the missionary process) they came to know God, or rather God came to know them (Gl 4:9). The word

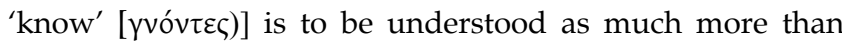
intellectual knowledge. It refers to relational interaction, mutual participation and intimate communication. It thus denotes the idea of people who journeyed together with God, and experienced God journeying with them (cf. Gl 5:25). It creates the picture of a faith community that grew ever deeper into their relationship with God. Therefore, it could be argued that the missionary impulse that brought them to

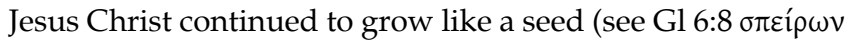

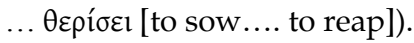

The missionary impulse is thus not to be seen as a once off moment of a missionary preaching the gospel, but the ongoing process of faith formation and community building. The missionary process thus does not end in the act of proclamation but continues as the word of God and the message of salvation takes root and grows to perfection. ${ }^{29}$ It is certainly within the faith community itself that the new paradigm for life is lived, where life is shared and where the effects of the transformative missional message are particularised. ${ }^{30}$ The missional message,thus, should naturally live on in (Longenecker 2009:205-221):

27.See, however, 1 Corinthians 5 (1 Cor 5:2; cf. also 5:5,7,11,13), where Paul urges the congregation to distinguish themselves from those who live 'unethically' by $\alpha \rho \theta \tilde{r}$

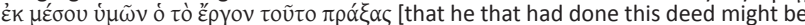
taken away from among you]. Here it could hardly be spoken of as a missionary dimension. When this point of view is fully developed and lived out concretely, dimension. When this point of view is fully developed and lived out concretely, it would lead to a distancing from all of those that live contra the core values of the congregation. On the other hand, in Galatians 6:1,Paul urges the community

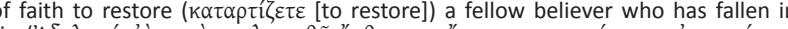

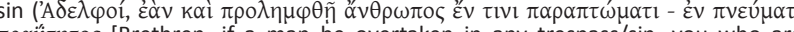

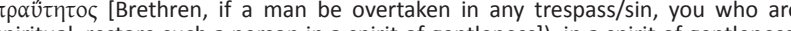
spiritual, restore such a person in a spirit of gentleness]), in a spirit of gentleness, but in the process to be careful not to fall in sin themselves. Here, according to Tolmie (2005:208-209), the focus shifts from the brother who has transgressed to the rest of the community of faith, who has the responsibility to restore the fallen brother in a gentle way into their former situation.

28.When the theological relativation of socio-cultural barriers are interpreted within the framework of identity, ethics and ethos, it would implicate that the followers of Christ should never be those who establish or maintain socio-cultural barriers that would inhibit the missionary process or inter-communal relationships. This mistake has been made in the past in some parts of the world like South Africa in the 'apartheid' system where church unity between different socio-cultural groups was not accepted.

29.Our understanding of mission should not be limited to the mere proclamation of the good message, without acknowledging the ongoing process of faith formation and community building as fundamental part of the missional process. If the definition of mission is thus broadened to include the process of faith formation, long after the original missionary message was received, the faith community itself becomes the locus of where the effects and working of the missionary dynamics are to be found. In this sense Bosch (1999:168) is correct when he argues that that not only is the church to be taken up in the misso Dei, but that it also should be sent into the world as the redeemed creation, to be in the world, for the world. Kritzinger (1994:41) agrees and argues that mission is to be defined as the church's participation of God's work in the world. In the latest research on Mission, scholars like Niemandt (2007), Roxburgh (2006), Keifert (2007:167-168) and Hirsch (2006) arees that mission is nourgh (2006), Keifert (2007.167-168) and Hirsch (2006) grees that mission is nothing less as to be taken op in Gods mission, and that it strongly is to be integrated with the ongoing process of faith formation and to have
an impact on the world.

30. Horrell (2009:207) is accurately argues that 'the indicatives express the terms in which the identity of the community is defined, while the imperatives call for action to reflect and sustain that identity'. 
- the concrete reciprocal ${ }^{31}$ love-life of the faith community

- the songs they sing

- the implicit ethics and the ethos

- the discipline

- the relationship to the state

- the relationship to the poor

- the relationship to the marginalised.

The original missional impetus thus becomes an inherent part of the life-movement of the community. The community, who once were the mission field, becomes the carrier of the transformative missional message, with the implicit potential to influence those around them.

\section{Regression into old thinking patterns}

Unfortunately, this was not always the case. In Galatians, we see a clear indication of a particular situation in the faith community where some have been led off the true spiritual path, leading directly to specific moral ${ }^{32}$ issues. Some members in the congregation regressed and fell back into (Gl 4:9) their formal spiritual state (and identity), when they were slaves of no good idols (G1 4:8), by again adhering to or

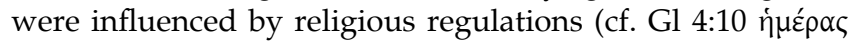

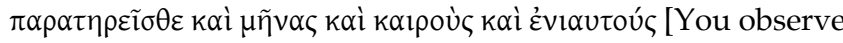
days, and months, and seasons, and years]) of weak and

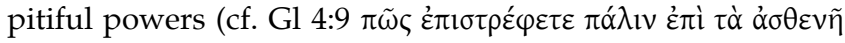

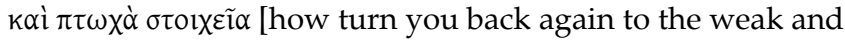
beggarly rudiments]). Some members did not act in love towards the others and, metaphorically speaking, almost devoured [á $v \alpha \lambda \omega \theta \tilde{\eta} \tau \varepsilon]$ each other (cf. Gl 5:15). Clearly, they did not walk in the Spirit (Gl 5:16) and did not let themselves be led by the Spirit. Those who belong to Christ, are supposed to have crucified their sinful nature (Gl 5:24) and should

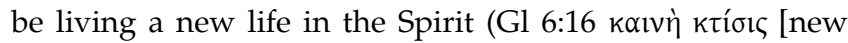
creation]), and walk in line accordingly (Gl 5:25). ${ }^{33}$ By falling back into their former state of being (or former identity), these members are living contra the recreated identity they have received, ${ }^{34}$ which inevitable leads to an embracing of certain elements of their former state of thinking (identity and ethics) and living accordingly (ethos). For Paul this is destructing the work that God began in them (Gl 3:5; 4:11) ${ }^{35}$

31.Wolter (2009:146-150) is correct when he argues that Galatians is to be understood against 'Das Prinzip der egalitären Reziprozität als Darstellung der paulinischen Ekklesiology' [The principle of equal reciprocity as representation of Paul's ecclesiology]. This becomes clear when one investigates the use of the term(s) ' $\dot{\alpha} \lambda \lambda \hat{n} \lambda \omega v$ ' [each other] (cf. GI 5:13, 15, 26; 6:2). For Paul, in Galatians the community of faith becomes the ideal context of the Christian way of life, so to say. It is especially (cf. GI 6:10b) within the community of faith that believers are to be on the lookout for the needs of the other members and where the fruit of the spirit should be lived out. It is especially within the community of faith that love should be nothing less than the 'Leitprinzip der christlichen Ethik' [Guiding principle of the Christian Ethics].

32.See note 2, previously, for my understanding of the term morality.

33. Horrell (2009:197) points to the fact that Bultmann (See Bultmann 1995:195-216) 'rejected the notion that the indicatives described a real or objective change in a person while the imperatives called for empirically distinct and identifiable behavior'. For Bultmann, it was rather the case that the moral demand to the believer has not acquired a new content and their moral conduct is only distinguishable from the conduct of others in that it carries the character of obedience. The implication is thus that the indicative relates to the self understanding of the believer, while the imperative refers to the action which is done as obedience." (Cf. also Bultmann 1964:76 and Furnish 2009:279).

34.Wright (2003) argues that the gift of faith and the declaration of God that believers are justified is something that derives from God and not in the first instance a result of the achievements of man. Therefore it is right to speak of the fact that believers have received a new identity from God.

35.According to Horrell (2009:208-209), in 1 Corinthians 5 it is clear that those who fall into sin, actually show by their lifestyle that they are not really children of God.Their sinful actions reveal their true identity; or rather (re)defines thei
Therefore it is not strange that we see Paul the missionary morally encouraging the community of faith, with rhetorical force, to adhere to the right conduct (ethos), based on the right understanding (ethics) of who they are in Christ (identity). ${ }^{36}$ Who they are, and should be in Christ goes back to the original plan of God when he sent his Son (Gl 1:4), and afterwards the apostle Paul (Gl 1:15; 2:2). This is the core of Paul's rhetorical purpose of the letter (Tolmie 2005:152-155), namely to remind the believers not to regress back into their old form of identity and by so doing become spiritual slaves again. In his rhetorical argumentation, Paul takes them back to a renewed understanding of their spiritual identity in Christ. According to Paul, they should realise the implications of the fact that they were transformed from slaves of idols and slaves of the law to children of God (Gl 4:1-7), and having the Spirit of the Son of God in their hearts (Gl 4:6), they are immersed and clothed in Christ (Gl 3:26-27). Those who let their lives (increasingly) be guided $^{37}$ by the Spirit ${ }^{38}$ are those who not only understand their identity, but also those who are free from the law (Gl 5:18). Their spiritual maturity should result in spiritual fruit (Gl 5:22vv). They are nothing less than a community of faith made free of all forms of bondage. ${ }^{39}$ The faithful freedom of this community is the compelling sign of those who belong to the heavenly Jerusalem over and against those who are still enslaved (cf. Gl 4:21-31) (Hahn 1965:101). Therefore, any approach denying or undermining the faithful freedom of the faith community is to be rejected, for it again enslaves the believers who have been set free and imposes a certain cultural group's socio-religious ethical demands on that of another. For this reason any approach that would lead to the restoration of the letter of the law ${ }^{40}$ and divisions amongst people is to be rejected ( $\mathrm{Rm} \mathrm{10:4;} \mathrm{Gl}$ 3:28), for believers are set free from the law that could not set them free from sin and death (cf. Gl 3:19ff). With the dawn of Christ's redemptive work on the cross (Gl 6:14), a life of new possibilities within the family of God (Gl 3:26-27) has been opened.

\section{Ethics of freedom: Missionary by nature}

It is, however, important to note that for Paul, men are not exempt from all forms of law or ethics, for judgment according to works still remain, ${ }^{41}$ but its outworking springs forth from another inherent source and motivation, namely

(Footnote 35 cont...)

identity. Furthermore, the sinful believer's identity (revealed by his or her sinful actions) indicates where he belongs, namely among the sinners of this world. Therefore the sinful believer is pushed out of the community of faith (1 Cor $5: 5,7,11,13)$ in order to protect the holy and faithful identity of the congregation.

36. Horrell (2009:208) argues in the same way in referring to Paul's strategy in 1 Corinthians 5: 'the community members need both to be reminded that they are the new and holy community of God - this is the positive identity which members enjoy - and that, as such, they must be that holy community, and take the action necessary to maintain that identity ...

37.Cf. the passive voice ó $\gamma \varepsilon \sigma \theta \varepsilon$ [to be led] in Galatians 5:18.

38.On the Spirit in Galatians, see 3:2; 3:3; 3:5; 3:14; 4:6; 4:29; 5:5; 5:16; 5:17; 5:18; $5: 22 ; 5: 25 ; 6: 1 ; 6: 8 ; 6: 18$.

39.For a discussion on the concept of freedom, see Bornkamm (1961:10).

40.See Martyn (1997:555-558) on the law in Galatians, cf. especially his discussion on the law of Christ in Galatians 6:2. Martyn refers to the watershed moment that changed the law (cf. GI 5:14) with reference to the Greek word pleroo.

41.Cf. also 2 Corinthians 5:10; Romans 14:10-12. 


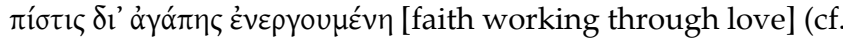
Gl 5:6) based on the Gesetz Christi (way or law of Christ), who showed the ultimate form of life in dying for us (cf. Gl 2:20). Without a holy life, in other words, without a high ethical life that results in spiritual fruit (Gl 5:22), the gospel would be nullified as liberating message of salvation and righteousness (Hahn 1965:103). Within the context of relational faith formation, the new life in Christ is guided by the Spirit (Gl 5:25), but lived in freedom (see Bornkamm 1961:6, 166) and in its scope and implication is directed universally (Gl 6:10) and inclusively in the context of love (cf. Gl 5:6) (see Watson 2007:213). According to Wolter (2009:146-150), ${ }^{42}$ love, within the context of egalitären Reziprozität (egalitarian reciprocity) (cf. $\dot{\alpha} \lambda \lambda \hat{n} \lambda \omega \nu$ [each other]) is to be seen as the Leitprinzip der Christlichen Ethik [leading principle of Christian ethics] and ultimately based on and motivated by the way or law of Jesus (Gesetz Christi) who died for us as an act of love (cf. Gl $2: 20)^{43}$. The theological category of freedom and good works (Gl 6:10), that have to be done in the context of love (Gl 5:6)

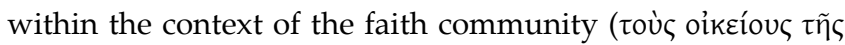

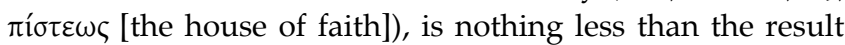
of Paul's missionary message that he received from God (cf. Gl 1:12) and that reflects the will of God (Gl 1:4). Long after Paul had preached his missionary message, the effect thereof (should) still live on in the context of the faith community as such. In other words, by understanding their freedom, and living from that freedom they are to be carriers of the missional message. They thus are to carry the same inclusive, universal message they have received from the apostle that same message that ultimately and intrinsically relates back to the original missional plan of God. This message has to be lived out in concrete ways and thus has an implicit performative, missio-ethical dimension. The characteristic of this 'living the message' will then carry with it the same sense of inclusiveness and the same sense of freedom. By living this way, the faith community, as incarnation of the message, in reality becomes nothing less than missionaries, as a result of the fact that every word and every action should inherently reflect the original missionary message that they have received. Paul often, in his letters, encouraged the faith communities to follow his example, that is modeled after that of Christ (cf. Rm 12:10; 1 Cor 4:16; 11:1; Eph 5:1; Phlp 3:17; 1 Th 1:6; 1:7; 2 Th 3:7; 3:9; 1 Tm 1:16; 4:12; 2 Tm 1:13; Tt 2:7). Following his example (in which he follows Christ), denotes a certain way of life (ethics and ethos), based on a certain understanding of their identity. The missionary process thus did not stop with Paul, but was intended to be continued in the ethical realisation of the life of the faith community. Therefore the faith community should by implication not only become the message, but also fundamentally missional

42.See Wolter (2009:146-150), who illustrates that the concept of dying for those one loves is also found outside of the New Testament (cf. Vita Philonidis 22 [To give your neck to those you love]; Plato, Symposiom 179b [To die for ones friends]. According to Wolter (2009:146-150), the concept of love for one another is also present in the Jewish Umwelt (environment) in the time of the early church (cf.

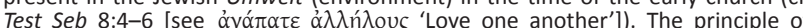
egalitären Reziprozität [egalitarian reciprocity] is also a concept that appears in the egalitaren Reziprozitat [egalitarian reciprocity] is also a concept that appears in the Umwelt of the early Christendom, not only in the Jewish, but also in the Hellenistic Umwelt (cf. Xenophon, Memorab. 2,7,1 [about Socrates]); Dio Chrysostomus, Or. of the day is clear from the motivation (based on what Christ has done) and the outworking thereof (has an ecclesiological focus).

43.Cf. also Romans 5:8, 2 Corinthians 5:14; Galatians 2:20; Ephesians 5:2, 25. in their being. ${ }^{44}$ They should be missional in the sense that the will of God, and the effects of that which God planned when he sent his Son and called (and sent) Paul, resulted in and relationally speaking between them. By becoming the embodiment of the message, they were taken up within the power of the message and were themselves nothing less than a light to others. ${ }^{45}$

In Galatians 6:10, Paul encourages the community to "Ap $\alpha$ oũv

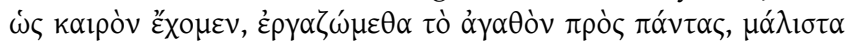

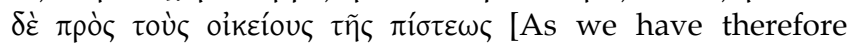
opportunity, let us do good unto all men, especially unto them who are part of the household of faith]. The construction

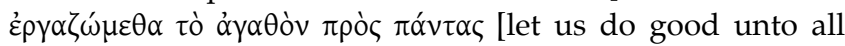

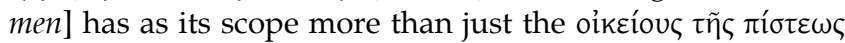
[household of faith].${ }^{46}$ Longenecker (2002:282) argues correctly that the inferential particle óp $\alpha$ [then], strengthened by the transitional particle oũv [therefore], appears frequently in Paul's letters. Here, according to him, it certainly signals the conclusion or main point of a discussion. ${ }^{47}$ The implication is that this particular verse is to be seen as the conclusion and main point not only of the directives given in 6:1-10 but also of all that has been said in 5:13-6:10:

In effect, the exhortations of 5:13, 'through love serve one another', and 6:10, 'do good to all people', function as an inclusio for all that Paul says against negative tendencies among the believers of Galatia in 5:13-6:10.

(Longenecker 2002:282)

Betz (1987) (cf. also Horrell 2005:264) also points to Paul's use of $\pi \alpha ́ v \tau \alpha$ [all] in 2:16; 3:8, 22, 26-28 and remarks:

The universal character of God's redemption corresponds to the universality of Christian ethical and social responsibility. If God's redemption in Christ is universal, the Christian community is obliged to disregard all ethnic, national, cultural, social, sexual, and even religious distinctions within the human community. ${ }^{48}$

44.In the source documents we do not have evidence of the actual missionary endeavours of die missional congregation. This obviously limits the discussion and has the danger of putting it within the context of speculation. We do, however, have very important heuristic categories that direct the reader towards a missiona hermeneutic understanding of the earliest congregations. Furthermore, from the perspective of speech act theory, it could be argued that Paul not only spoke ertain words in the missional direction, but did something with those words. His words were aimed at moving the congregation, of inspiring them to action and, as we have proved, this certainly included a persuasion towards at least some sort of missional action. This is seen for instance in Galations 6:9-10.

45.Cf. the same train of thought in Philippians 2:15 and in the Pauline tradition of

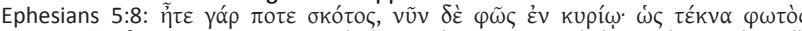
$\pi \varepsilon \rho 1 \pi \alpha \tau \varepsilon i \tau \varepsilon$ [For you were once darkness, but are now light in the Lord: walk therefore as children of light] (cf. the present imperative active).

46.See Becker and Luz (1998:95-96), who touches on the missionary dimension. On the other hand, Rohde (1989:268-268) does not mention the missionary dimension in his discussion of Galatians 6:10.

47.Cf. also Romans 5:18; 7:3, 25; 8:12; 9:16, 18; 14:12, 19; Ephesians 2:19; 1 Thessalonians 5:6; and 2 Thessalonians 2:15

48.See Wolter (2009:143), who also agrees and argues: 'Heindenchristen und Judenchristen trotz ihres unterschiedlichen Ethos ein und dieselbe Identität haben' [Pagan and Jewish Christians share the same identity despite their different Ethos], but on the other hand, 'Es ist mithin das "Ethos" des Glaubens (Gn. epexegeticus), das die Christen nach Aussen abgrenzt und dadurch die Exklusivität ihrer Identität repräsentiert. Das ist möglich, weil eben der Glaube, der bei Paulus natürlich immer pistis Xristou ist und durch seine Bezogenheit auf Jesus Christus definiert wird, eine Gemeinsamkeit herstellt, die die Differenz zwischen Juden und Heiden umgreift (vgl. Röm 1,16; Gal 5,6) und die Christen von den nichtchristlichen Juden und Heiden significant unterscheidet' [It is, therefore, the 'ethos' of faith (Gn. epexeticus), which defines and separates the Christians to the outside and epexegeticus), which defines and separates the Christians to the outside and thereby representing the exclusiveness of their identity. This is possible precisely because the faith that is in Paul of course, is always pistis Xristou (faith in Christ) and defined by the believer's relationship to Jesus Christ which creates a common bond, which encompasses the difference between Jews and Gentiles (cf. Rm 1:16;
GI 5, 6) and significantly differentiates Christians from non Christian Jews and pagans alike]. 
Since before God there is no partiality, there cannot be partiality in the Christian's attitude towards his fellow man.

(Betz 1987:311)

This is probably one of the most obvious negative implications for those in Paul's day who forced a particularistic ethnic Jewish ethic on the socio-cultural diverse community of faith. This would have worked directly against the dynamics of the missionary process because of the fact that it might again reaffirm traditional exclusivist practices. Paul never did this in his missionary approach. In the context of Galatians 6:10, Paul rhetorically persuades the community of faith to not only realise their identity, ethics and ethos but also to do that

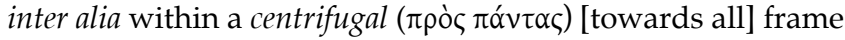
of reference. In other words, a frame of reference directed also towards those outside of the faith community and not only centripetally to those inside. Here Paul is not referring to mission as something that someone does somewhere, or is sent to do, but something essential to being a Christian. Being missional is thus part and parcel of being a Christian, it is existentially part of the ' $D N A$ ' of the Church, who should be missionary by its very nature. We should rather not speak of doing mission or sending people on missionary projects, but rather of being missional, right there where we are in everything we do (Guder \& Barrett 1998:1-17).

\section{Conclusion}

From the preceding discussion, we could infer that there is not only a dynamic inter-relational relationship between identity, ethics and ethos, but also between the latter and the missionary movement of the early church (with reference to Paul's letter to the Galatians). It is clear that the implication of Paul's rhetorical approach in Galatians should lead to the reality of the faith community becoming the embodiment of the missional message preached by the missionary Paul. Paul's personal transformation of his identity, ethics and ethos becomes not only the message he preaches, but also the tipos,

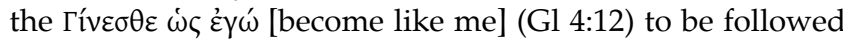
by the congregations that he found on the missionary field. His tipos is again related to that of Christ, who has been sent by God and thus is understood to represent something of the missional plan of God. In times of crisis and delineation from the right path of life Paul encourages the congregation by inter alia, rhetorically taking them back to a reaffirmation of their true identity, and the ethical dimension that flows from that. ${ }^{49}$

In the dynamics of Paul's missionary work, we clearly see a focus on the elements of identity, ethics and ethos, which fundamentally relates to the symbolic universe of the missionary. Thus, when we speak of mission in Galatians, we have to acknowledge the fact that, from a rhetorical point of view, it was the apostle's wish that the missional movement did not stop with his missional preaching, ${ }^{50}$ but continued

49.See Horrell (2009:208) for a similar argument.

50.Koester (1989:185-186) argues: 'Doesn't his theology lead to passivity rather than concern for action? Paul's own autobiography issues a resounding "No" to these questions. Paul himself was anything but passive. The gospel he preached was not "an opiate for the people," but an "adrenaline for mission." The gospel moved him beyond the bounds of his Jewish heritage into the world around him'. in process as the faith community becomes the carrier and embodiment of the missionary message. We have argued earlier that Paul, rhetorically, tries to move the congregation to realise their identity (as well as ethics and ethos) not only within a centripetal (inwards, towards themselves) but also

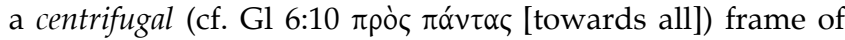
reference, directed inter alia towards those outside of the faith community. Thus, their transformed identity in Christ should not only lead to a new ethics, but also to a new ethos, in the form of a new lifestyle, that should impact society around them. In this way the faith community becomes missional by implication, because they embody the missional message and its impact potentiality. We could, in other words, infer from this that it is possible to broaden the scope of missional hermeneutics and speak of missional congregations ${ }^{51}$ in the early church and that being missional is inseparable from ethics, and ethics inseparable from the missional dimension. Those who want to speak of mission should also speak of ethics, and those who speak of ethics should make something of mission. As I have stated in the beginning of the article, we could concur with scholars like Keifert (2006:167-168), that the Pauline understanding of mission is that mission is to be understood as something far greater than the church, a dimension in which the missional church is to be taken up into and to carry out God's mission (cf. also Bosch 1999). A missional church is, in other words, a church that does not simply do mission, but focus on being missional (Keifert 2006:168)

\section{References}

Becker J. \& Luz, U., 1998, 'Die Briefe an die Galater, Epheser und Kolosser', NTD 8/1, Vandenhoek \& Ruprecht, Göttingen.

Betz, H.D., 1987, Galatians, Hermeneia: A Critical and Historical Commentary on the Bible, Fortress, Philadelphia.

Bornkamm, G., 1961, Das Urchristliche Verständnis von der Freiheit, The Neckarauer Hefte 8, Evangelische Verlag Comtesse, Heidelberg.

Bosch, D.J., 1999, Transforming mission, paradigm shifts in theology of mission, Orbis Books, New York.

Breytenbach, C., 2005, 'The 'for us' Phrases in Pauline soteriology, considering their background and use', in J.G. van der Watt (ed.), Salvation in the New Testament, pp. 163-185, NonTSup 121, Brill, Leiden.

Bultmann, R., 1964, Jesus Christ and mythology, SCM Press, London.

Bultmann, R., 1995, 'The problem of ethics in Paul', in B.S. Rosner (ed.), Understanding Paul's Ethics, pp. 195-216, Eerdmans, Grand Rapids,

Burridge, R.A., 2007, Imitating Jesus: An inclusive approach to New Testament ethics, Eerdmans, Grand Rapids.

Campbell, J., 2005, The way of Jesus, Jossey-Bass, San Francisco.

Cromhout, M., 2009, 'Paul's "former conduct in the Judean way of life" (Gal 1:13)...or not?', HTS Teologiese Studies/Theological Studies 65(1), Art. \#127, 12 pages. DOI: not?, 10.4 / 10 hts.v65i1.127.

Du Toit, A.B., 2007, 'Encountering grace, towards understanding the essence of Paul's Damascus experience', in C. Breytenbach \& D.S. du Toit (eds.), Focusing on Paul, Persuasion and Theological Design in Romans and Galatians, pp 57-76, BZNW 151, De Gruyter, Berlin.

Dunn, J.D.G, 1998, The theology of the apostle Paul, Eerdmans, Grand Rapids.

Dunn, J.D.G., 2008, The new perspective on Paul, Eerdmans, Grand Rapids.

Du Plessis, J., Orsmond, E., \& Van Deventer, H.J. (eds.), 2009, Missionary perspectives in the New Testament: Pictures from chosen New Testament literature, BybelMedia, Wellington.

Engberg-Pederson, T., 2000, Paul and the Stoics, Westminster John Knox, Louisville.

Furnish, V.P., 2009, Theology and ethics in Paul, Westminster John Knox Press, Louisville.

51.It is clear when one has a clear look at Philippians 4:15; 2 Corinthians 11:7-11; and Acts 16:14-15, that some congregations supported Paul financially with reference to the missionary work he was doing. Clearly, from this it could also be argued to the missionary work he was doing. Clearly, from this it could also be argued
that some congregations in the early church had sensitivity towards the missionary that some congregations in the early church
dimension (Lietaert Peerbolte 2003:222). 
Gager, J.G., 2000, Reinventing Paul, Oxford University Press, Oxford.

Guder, D.L. \& Barrett, L. (ed.), 1998, Missional church, A vision for the sending of the church, Grand Rapids, Eerdmans.

Hawthorne, G.F., Martin, R.P. \& Reid, D.G., 1993, Dictionary of Paul and his letters, InterVarsity Press, Downers Grove.

Hahn, F., 1965, Mission in the New Testament, SCM Press, London.

Hauwerwas, S., 1983, The Peaceable Kingdom: A primer in Christian ethics, University of Nortre Dame Press, Nortre Dame.

Hirsch, A., 2006, The forgotten ways, Brazos Press, Grand Rapids.

Horn, F.W., 2009, 'Die Darstellung und Begründung der Ethik des Apostels Paulus in der New Perspective', in R. Zimmermann \& F.W. Horn (Hrsg.), Jenseits von Indicativ und Imperativ, , WUNT 238, pp. 213-234, Mohr Siebeck, Tübingen.

Horrell, D.G., 2002, 'The significance of Paul's story', in B.W Longenecker (ed.), Narrative dynamics in Paul, a critical assessment, pp. 157-171, Westminster John Knox Press, Louisville.

Horrell, D.G., 2009, 'Pauline ethics in 1 Corinthians 5', in R. Zimmermann \& F.W. Horn (eds.), Jenseits von Indicativ und Imperativ, WUNT 238, pp. 197-212, Mohr Siebeck, Tübingen.

Jenkins, P., 2002, The Next Christendom, Oxford University Press, Oxford. doi: 10.1093/0195146166.001.0001

Keck, L.E., 1979, 'Das Ethos der Frühen Christen', in W.A. Meeks (Hrsg.), Zur Soziologie des Urchristentums, TB 62, pp 128-147, Kaiser, Munich.

Keifert, P., 2006, We are here now: A new missional era, Allelon, Idaho.

Koester, C., 1989, Opportunity to do good: The letter to the Galatians, Word \& World 9/2, Luther Seminary, St. Paul, Minnesota.

Kok, J., 2010, 'Rediscovering a missional incarnational ethos in John 4', in R Zimmermann \& J.G. Van der Watt (eds.), Moral language in the New Testament pp. 168-193, Mohr Siebeck, Tübingen.

Kok, J., 2010b, 'The new perspectives on Paul and its Implication for Mission', Acta Patristica et Byzantina (forthcoming).

Kritzinger, J.J., Meiring, P.G.J., \& Saayman, W.A., 1994, On being witnesses, Orion Halfwayhouse.

Le Grys, A., 1998, Preaching to the nations: The origins of mission in the early church, SPCK, London.

Lietaert Peerbolte, L.J., 2003, Paul the missionary, Peeters Press, Leuven.

Longenecker, B.W., 2002. Narrative dynamics in Paul: a critical assessment, Westminster John Knox Press, Louisville.

Longenecker, B.W., 2009, 'The Poor of Galatians 2:10, The interpretative paradigm of the first four centuries', in B.W. Longenecker \& K.D. Liebengood (eds.), Engaging economics, New Testament scenarios and early christian reception, pp. 205-221, Eerdmans, Grand Rapids.

Longenecker, R.N., 2002, Galatians, Word Biblical Commentary Series vol. 41, Word Incorporated, Dallas.

Martyn, J.L., 1997, Galatians, The Anchor Bible Dictionary Commentary Series, Anchor Bible, New York.

Meeks, W.A. (ed.), 1979, Zur Soziologie des Urchristentums, TB 62, Kaiser, Munich

Meeks, W.A. (ed.), 1993, The origins of Christian morality, Yale University Press, New Haven.

Merriam-Webster, 2003, Merriam-Webster's collegiate dictionary, Merriam-Webster Springfield.

Newbigin, L., 1995, The open secret, introduction to the theology of mission, Eerdmans, Grand Rapids.
Niemandt, N., 2007, Nuwe drome vir nuwe werklikhede, Lux Verbi, Wellington.

Nissen, J., 2007, New Testament and mission: Historical and hermeneutical perspectives, Peter Lang GMBH, Frankfurt.

Odendal, F., 1994, Die elektroniese weergawe van die verklarende handwoordeboek van die Afrikaanse taal, Perskor Uitgewery, Midrand.

Pesce, M., 1994, Le due fasi della predicatione di Paolo. Dall' evangelizzazione alla guida della communita, Studi Biblici 22, Bologna, Edzioni Dehoniane.

Reinbold, W., 2000, Propaganda und Mission im ältesten Christentum: Eine Untersuchung zu den Modalitäten der Ausbreitung der Frühe Kirche, FRLANT 188, Untersuchung zu den Modalitäten der
Vandenhoeck\&Ruprecht, Göttingen.

Robert, D.L., 2005, American woman in mission: A social history of their thought and practice, Mercer University Press, Mercer.

Rohde, J., 1989, Der Brief des Paulus and die Galater, Evangelische Verlagsanhalt, Berlin.

Roxburgh, A., 2006, The sky is falling, Allelon, Idaho.

Sanders, E.P., 1977, Paul and Palestinian Judaism, SCM, London.

Sanders, E.P., 1983, Paul, the law and the Jewish people, Fortress Press, Philadelphia.

Schnelle, U., 2003, 'Die Begründung und die Gestaltung der Ethik bei Paulus', in Die bleibende Gegenwart des Evangeliums, MthSt 76, pp. 109-131, FS Otto Merk, Marburg.

Schnelle, U., 2009, Theology of the New Testament, Baker Academic, Grand Rapids.

Tolmie, D.F., 2005, Persuading the Galatians, WUNT 190, Mohr Siebeck, Tübingen.

Van der Watt, J.G. (ed.), 2005, Salvation in the New Testament, perspectives on soteriology, NonTSup 121, Brill, Leiden.

Van der Watt, J.G. (ed.), 2006, Identity, ethics and ethos in the New Testament, BZNW 141, De Gruyter, Berlin.

Van der Watt, J.G., 2000, Family of the King: The dynamics of metaphor in die Gospel of John, Brill, Leiden.

Van der Watt, J.G., 2004, 'Directives for the Ethics and Ethos Research Project', paper presented at the Identity, Ethics and Ethos project meeting, University of Pretoria, Pretoria, August 02-03.

Van der Watt, J.G. \& Kok, J., 2010, 'Violence in John', in J.W. Van Henten \& P.G.R. de Villiers (eds.), Violence in the New Testament, Brill, Leiden (forthcoming).

Van Rensburg, F.J., 2005, 'Ethics in 1 Peter', paper presented at the Identity, Ethics and Ethos project meeting, University of Pretoria, Pretoria, August n.d.

Watson, F., 2007, Paul, Judaism, and the Gentiles: Beyond the New Perspective, Eerdmans, Grand Rapids.

Wolter, M., 2009, Theologie und Ethos im Frühen Christentum, WUNT 236, Mohr Siebeck, Tübingen.

Wright, N.T., 2003, 'New perspectives on Paul', unpublished paper presented at the 10th Edinburgh Dogmatics Conference, Rutherford House, Edinburgh, August
$25-28$, viewed 16 September 2010, from http://newpaul.blogspot.com/

Zimmermann, R., 2007, 'Jenseits von Indikativ und Imperativ. Entwurf einer “impliziten Ethik" des Paulus am Beispiel des 1 Korintherbriefes', Theologische Zeitschrift 132, 259, 284.

Zimmermann, R., 2009, 'The "implicit ethics" of New Testament Writings: A Draft on a New Methodology for Analysing New Testament Ethics', Neotestimentica 43(2), 399-423.

Zimmermann, R. \& Van der Watt, J.G. (eds.), 2010, Moral language in the New Testament, Mohr Siebeck, Tübingen. 